\title{
О ВОЗМОЖНОСТИ МЕЖДИСЦИПЛИНАРНОЙ ИНТЕГРАЦИИ РУССКОГО ЯЗЫКА И ХИМИИ В СТАРШИХ КЛАССАХ ОБЩЕОБРАЗОВАТЕЛЬНОЙ ШКОЛЫ
}

Костионова Д.Ю., Сиголаева Т.Е., Мишина А.В.

Тульский государственный педагогический университет им. Л.Н. Толстого, г. Тула, Российская Федерация

Проведено исследование в области междисциилинарной интеграичи русского языка и химии в старших классах общеобразовательной школьл.

Ключевые слова: междисииплинарный; обучающийся; орфография; химия; способность; общеобразовательная школа; грамотность.

\section{ON THE POSSIBILITIES OF INTERDISCIPLINARY INTEGRATION OF THE RUSSIAN LANGUAGE AND CHEMISTRY IN HIGH SCHOOL}

\section{Kostyonova D.Yu., Sigolaeva T.E., Mishina A.V.}

Tula state Lev Tolstoy pedagogical University, Tula, Russian Federation

A study in the field of interdisciplinary interference of the Russian language and chemistry in high school.

Keywords: interdisciplinary; studying; spelling; chemistry; ability; secondary school; literacy.

Одной из важнейших проблем современного общества 21 века, это полное отсутствие грамотности у молодого поколения. Не знание родного языка делает общество примитивным, подверженным быстрой деградации. 
В наше время, школе необходимо применять более современные приемы по развитию способностей у обучающихся к изучению родного языка, основным его правилам. Безусловно, прививать любовь к русскому языку и передавать некоторые знания, долг только самого учитель русского языка, но не так все просто в нашем мире, при постоянно меняющихся условиях, меняющейся культуре и нравах, школьнику мало только уроков русского языка. Не стоит забывать, что родной русский язык не только предмет изучения, но и выступает средством обучения тоже. Родной язык - основа всех наук. Следовательно, необходимо прививать обучающимся культуру речи усилиями всех педагогов.

Безусловно, на уроках физики, химии, естествознания и биологии учителя дают знания не только по профилю, но и учат школьников правильно говорить, не делать ошибки в лексике и правописании. На наш взгляд, добиться наибольшей эффективности при достижении главной цели - развитие речи обучающихся, удастся только тогда, когда появится возможность к проведению интегрированных междисциплинарных уроков разного уровня. В наши дни, не редкость интегрированных уроков, устанавливающих междисциплинарные связи. Но для чего нужны междисциплинарные уроки химии и русского языка? Прежде всего для того, чтобы сформировать у обучающихся прочные орфографические навыки, для развития умения выражать свои мысли четко, грамотно, логично.

Как правило, только на уроках русского языка и литературы педагог отслеживает правильное написание слов, следит за орфографическими ошибками детей, правильным произношением слов и верными ударениями.

Многие учителя предметники, крайне не внимательно относятся к грамотности школьников на своих уроках, тем самым порождая всеобщую неграмотность.

Далее, Вашему вниманию будет представлен разработанный комплекс интегрированного обобщающего урока по теме: «Азот, оксиды азота и их свойства». В котором, на конкретном примере будет показана методика отработки правильной орфографии и синтаксиса. Ведь не все учителя, сами того не зная, делают грубейшие ошиб- 
ки в произношении химических терминов и их написание. Целью данного урока является, не только закрепление полученных знаний о азоте и его оксидах, умение обучающихся составлять уравнения реакций и проводить расчеты по уравнениям реакций, но и формирование способности самостоятельно выявлять видимые различия между односоставными и двусоставными предложениями в русском языке и верным произношением отдельных терминов.

В начале урока обучающимся предлагается выразительно прочитать стихотворение, написанное на доске и расставить недостающие буквы.

Лавуазье ск...жу спасибо,

Ведь он ... ткрыл меня.

И, поверьте, мне ...бидно,

Что не ...ктивным называюсь я.

Все бе...жизненным сч...тают,

А ведь главн...го не знают,

Я в состав белков вх...жу,

Я с м...таллами ...

Чаще в виде уд...брений.

Таким образом, мы подводим обучающихся к теме урока и предлагаем новые задания:

1. Дайте подробную характеристику азота по положению в периодической системе Д.И. Менделеева;

2. Перечислите все возможные свойства азота (химические и физические);

3. Расскажите, как получают азот в лаборатории и промышленности (приведите уравнения реакций);

Некоторые учащиеся могут работать с карточками:

\begin{tabular}{|c||}
\hline \multicolumn{1}{|c||}{ Карточка №1 } \\
Допишите пропущзенные слова: \\
Азот - это ...Он ...воздуха, ...в воде, легко реагирует с дру- \\
гими ..., при этом образуются сложные соединения, которые \\
называют... \\
\hline
\end{tabular}




\section{Карточка №2}

Составьте словосочетания по схеме, допишите буквы:

\section{Существительное + прилагательное.}

Пример: решетка кристаллическая.

Пробирка, токсичная, катализатор, кислота, вода, оксид, прибор, щелочь, эксперимент, ядовитая, опасная, молекулярная, радиоактивная.

Тем временем, пока некоторые учащиеся работают с карточками, с оставшимися учащимися преподаватель проводит фронтальный опрос.

Преподаватель может задать вопрос о возможной валентности азота. С какими веществами реагирует кислород? Какие соединения при этом образуются? Обучающиеся дают определение понятию «оксид», рассказывают, как классифицируют оксиды, где их применяют, с какими веществами реагируют?

В конце урока ученикам можно задать такие вопросы: какими по структуре предложениями вы пользовались при ответах на вопросы? Какой стиль речи использовал учитель и учащиеся?

Можно предложить обучающимся проанализировать свои ответы и отметить тех, кто отвечал на уроке наиболее грамотно с точки зрения правил русского языка, а также вспомнить ответы, химически правильные, но не совсем грамотные.

\section{Выводы}

После проведения ряда подобных занятий нами было выявлено, что обучающиеся и на других уроках стараются следить за своей речью, учатся быстро находить ошибки в ответах товарищей, у них формируется мотивация к изучению родного языка.

У каждого гражданина своей страны, независимо от его профессии в будущем, нужно воспитывать ответственность за грамотное письмо и умение выражать свои мысли четко и логично. Чувство речевой и орфографической уверенности должно быть развито, как чувство собственного достоинства. 